\title{
Akulturasi Minangkabau - Melayu Melalui Musik dan Tari di Batu Bara Sumatera Timur
}

\author{
Muhammad Yusuf \\ Madrasah Aliyah Negeri 2 Kota Serang Provinsi Banten \\ E-mail: yusufkamga@gmail.com
}

\begin{abstract}
This research discusses the process of acculturation of the Minangkabau ethnic Bansi traditional musical instrument which is included in the accompaniment of the Ethnic Melayu in Gobuk dance. The purpose of this study was to determine how the acculturation of Bansi Minangkabau musical instruments to the gobuk dance accompaniment in Batu Bara Regency, East Sumatra, North Sumatra Province. The theoretical basis used in this research is acculturation theory, function theory, meaning theory and musical accompaniment. The research method used is descriptive qualitative. The population in this study were art studios / institutions in Batu Bara Regency which contained elements of art. The sample of the research is an Art Institute called the YUSDA Arts Institute. To complement the data in this study, researchers conducted field observations, literature study, documentation in the form of videos and photos and conducted interviews. Based on the data collected, it can be seen that the musical instruments used in the gobuk tradition include drums, gongs or tawak-tawak, bansi, and violins. The ancestors of the Batu Bara community came from Pagaruyung (Bukittinggi) of West Sumatra. The process of acculturation of the Bansi musical instrument occurred due to the subsequent distribution of the ancestors of the Batu Bara community, who were predominantly from pagaruyung (Bukittinggi). The form and presentation of the gobuk tradition goes through several stages, namely the ritual preparation stage, the possession stage, the aw areness stage, and the closing stage. The function of the gobuk tradition itself can be categorized into several things, namely; as ritual, as healing and as performance. It is hoped that from this research, other similar studies will be born and dig deeper into the forms of acculturation in North Sumatra, especially East Sumatra.
\end{abstract}

Keywords: acculturation, Minangkabau, Malay, East Sumatera

\begin{abstract}
Abstrak: Penelitian ini membahas proses akulturasi alat musik tradisional Bansi Etnis Minangkabau yang masuk pada alat musik iringan Tari Gobuk Etnis Melayu. Tujuan penelitian ini untuk mengetahui bagaimana terjadinya akulturasi alat musik Bansi Minangkabau pada iringan tari gobuk di Kabupaten Batu Bara Sumatera Timur Provinsi Sumatera Utara. Landasan Teori yang digunakan pada penelitian ini menggunakan teori akulturasi, teori fungsi, teori makna dan musik iringan. Metode penelitian yang digunakan adalah deskriptif kualitatif. Populasi dalam penelitian ini adalah sanggar/lembaga kesenian di Kabupaten Batu Bara yang memuat unsur seni. Sampel dari penelitian merupakan sebuah Lembaga Kesenian bernama Lembaga Kesenian YUSDA. Untuk melengkapi data-data dalam penelitian ini, peneliti melakukan observasi lapangan, studi kepustakaan, dokumentasi berupa video dan foto-foto serta melakukan wawancara. Hasil penelitian berdasarkan data yang terkumpul, dapat diketahui bahwa Alat musik yang digunakan pada tradisi gobuk antara lain, gendang, gong atau tawak-tawak, bansi, dan biola. Nenek Moyang masyarakat Batu Bara berasal dari pagaruyung (Bukittinggi) Sumatera Barat. Proses terjadinya akulturasi alat musik bansi terjadi akibat ikutnya terjadi persebaran nenek moyang masyarakat Batu Bara sendiri yang dominan berasal dari pagaruyung (Bukittinggi). Bentuk dan penyajian tradisi gobuk melalui beberapa tahapan yaitu tahap persiapan ritual, tahap kerasukan, tahap kesadaran, dan tahapan penutupan. Fungsi dari tradisi gobuk sendiri dapat dikategorikan pada beberapa hal, yaitu; sebagai ritual, sebagai penyembuhan dan sebagai pertunjukan. Diharapkan dari penelitian ini nantinya akan lahir penelitian lainnya yang sejenis dan lebih menggali lebih dalam lagi bentuk-bentuk akulturasi kebudayaan yang ada di Sumatera Utara khususnya Sumatera Timur.
\end{abstract}

Kata Kunci : Akulturasi, Minangkabau, Melayu, Sumatera Timur.

\section{PENDAHULUAN}

Budaya merupakan sebuah kebisaan yang lahir atas dasar perilaku sehari-hari yang dianggap berkaitan erat dengan kehidupan dan proses perilaku kebiasaan itu menjadi sebuah budaya dan diterima untuk dijadikan kebudayaan dalam masyarakat tertentu. Setiap suku bangsa di dunia 
memiliki kebudayaan yang berbeda satu dengan yang lain. Perbedaan tersebut menjadi keragaman tersendiri sebagai sebuah fenomena budaya. Menurut Tuti Rahayu (2005:01) kebudayaan ialah : "Terwujud oleh tingkah laku, bahasa, upacara, kesenian dan adat istiadat masyarakat yang melembaga. Dalam proses perkembangan yang terjadi antara kebudayaan yang satu dengan yang lain memberi proses saling sentuh yang kemudian akan membawa dampak besar terhadap eksistensi dan fenomena datangnya budaya baru."

Tari Gobuk atau Kesenian gobuk menurut Pak Padil (wawancara 2016) merupakan sebuah tradisi masyarakat pesisir yang digunakan untuk proses penyembuhan. Pada awalnya tari gobuk adalah sebuah upacara ritual pengobatan. Awal mula kesenian yang memuat tarian ini berawal pada sekitar tahun 1895 lalu ketika ada seorang warga Desa Lima Laras Kecamatan Tanjung Tiram yang merupakan anak dari seorang penguasa desa mengalami sakit.

Akulturasi yang terjadi pada musik iringan Tari Gobuk di Kecamatan Tanjung Tiram Kabupaten Batu Bara menjadi sebuah perhatian peneliti dikarenakan adanya alat musik di luar dari alat musik Melayu sendiri. Terdapatnya alat musik bansi yang merupakan alat musik minangkabau tentu menjadi sebuah temuan yang menarik untuk dijadikan sebuah penelitian, mengingat alat musik ini umumnya digunakan pada musik tradisional minangkabau sendiri. Secara bentuk, struktur Musik pada iringan tari gobuk di Kecamatan Tanjung Tiram juga akan dikaji bagaimana proses penyajian musik dalam mengiringi tari gobuk. Dalam penelitian ini juga akan dikaji fungsi Tari Gobuk bagi masyarakat Melayu pesisir di Kecamatan Tanjung Tiram Kabupaten Batu Bara sendiri serta peran ritual gobuk itu sendiri. Melihat terdapatnya akulturasi alat musik tersebut, tentu akan dijelaskan juga alat musik apa saja yang digunakan dalam memainkan musik pengiring tari Gobuk.

Akulturasi merupakan sebuah proses peleburan sebuah budaya tertentu untuk dimasukkan ke dalam identitas budaya lain yang dilakukan secara bertahap, sehingga terjadi sebuah proses pembaharuan dalam kebudayaan yang dimasuki tanpa menghilangkan budaya penyusunnya. Menurut Iwan Awaluddin Yusuf
(2005:26) ; "Dalam kerangka pembaruan inilah kadang muncul subkultur dan budaya-budaya baru yang saling tumpang tindih. Secara alamiah proses akulturasi akan berkangsung secara bertahap dan selektif, namun dalam suatu negara yang menerapkan politik etnik, akulturasi kerapkali dijadikan sebagai upaya untuk melakukan penetrasi sistem budaya lain atau digunakan untuk mengadopsi budaya asing".

Akulturasi menjadi sebuah lapangan studi antropologi di Amerika Serikat dibicarakan pertama kali pada pertemuan tahunan dari American Anthropological Association tahun 1930. Berdasarkan perumusan yang dibuat oleh Robert Redfield, Ralph Linton dan Melville J. Herskovits dari Sub Komite Akulturasi dalam Kongres Social Science Research Council 1930, yang dimuat sebagai "Memorandum for the Study of Acculturation", American Anthropologist, Vol. 38 No. 1 (Januari-Maret 1936), h. 136, mengatakan bahwa akulturasi adalah:"... comprehends those phenomena which result when groups of individuals having different culture comes into continous first hand contact, with subsequent changes in the original cultural patterns of either or both groups. Proses akulturasi sebenarnya telah ada sejak sejarah manusia dimulai, tetapi akulturasi yang menunjukan sifat aslinya secara khusus baru timbul ketika kebudayaan bangsa-bangsa di Eropa Barat mulai menyebar ke semua daerah lain di muka bumi dan mulai mempengaruhi masyarakat suku-suku bangsa di Asia, Afrika, Oseania Amerika Utara dan Amerika Latin (Yusuf, 2005 :27).

Menurut Purba (2007:2), musik tradisional tidak berarti bahwa suatu musik dan berbagai unsur-unsur di dalamnya bersifat kolot, kuno atau ketinggalan zaman.Namun, musik tradisional adalah musik yang bersifat khas dan mencerminkan kebudayaan suatu etnis atau masyarakat.

Musik Tradisional juga musik yang lahir dan berkembang disuatu daerah tertentu dan diwariskan dari suatu generasi ke generasi berikutnya. Musik ini menggunakan bahasa, gaya, dan tradisi khas daerah setempat, dan dari situlah kita bisa mengetahui bahwa alat musik tradisional itu berasal daerah mana, sehingga musik 
tradisional tidak dapat dipisahkan dengan daerah itu sendiri.

Pengiring berasal dari kata dasar iring yang berarti bersama-sama; diikuti dengan (Sugiyono 2008 : 375), sedangkan pengiring adalah orang dan sebagainya yang mengiringi; pengikut. Dapat disimpulkan pengiring mempunyai arti orang atau benda yang bertugas sebagai pengikut dari sesuatu hal yang menjadi patokan bagi pengiring tersebut, biasanya pengiring selalu berada di belakang dan mempunyai peran yang sangat penting dari hal yang diiringi.

Menurut Wiliam A. Havilland (2009:100)

Bentuk merupakan sebuah istilah yang memiliki beberapa pengertian. Dalam seni dan perancangan, istilah bentuk seringkali dipergunakan untuk menggambarkan struktur formal sebuah pekerjaan yaitu cara dalam menyusun dan mengkoordinasi unsur-unsur dan bagian-bagian dari suatu komposisi untuk menghasiLembaga Kesenian an suatu gambaran nyata. Bentuk dapat dihubungkan baik dengan struktur internal maupun garis eksternal serta prinsip yang memberikan kesatuan secara menyeluruh.

Fungsi pada dasarnya adalah sistem yang saling berkaitan antara unsur-unsur pembentuknya. Suatu budaya musik mencakup gagasan-gagasan, tindakan, karena musik adalah suatu gejala manusia, untuk manusia dan mempunyai fungsi sosial dalam situasi sosial. Hal ini karena berbagai unsur dalam sistem bersifat fungsional. Fungsi sosial musik dalam masyarakat harus dilihat bahwa musik itu berperan dan dapat memberi, sehingga ia dapat bertahan dalam kehidupan masyarakat.

Alan P. Merriam mengatakan (1964 : 219), "fungsi musik merupakan masalah yang sangat penting dalam etnomusikologi (ilmu perbandingan musik yang bertujuan memperoleh pengertian tentang sejarah asal usul, perkembangan, dan persebaran musik pada berbagai bangsa di dunia), karena hal ini menyangkut makna dan tujuan pemakaian musik dalam pandangan yang luas, artinya mengapa musik tersebut digunakan demikian”. Berkenaan dengan fungsi musik, menurut Alan P. Merriam terdapat sekurang-kurangnya sepuluh fungsi musik, yaitu : (1) fungsi pengungkapan emosional, (2) fungsi penghayatan estetika, (3) fungsi hiburan, (4) fungsi komunikasi, (5) fungsi perlambangan, (6) fungsi reaksi jasmani, (7) fungsi pengesahan lembaga sosial dan upacara keagamaan, (8) fungsi yang berkaitan dengan norma-norma sosial, (9) fungsi kesinambungan kebudayaan, dan (10) fungsi pengintegrasian (pembaruan menjadi kesatuan yang utuh) masyarakat (1964:219-226).

Kabupaten Batu Bara Pada tanggal 15 Juni 2007, resmi menjadi daerah tingkat II ke-26 Propinsi Sumut. Peresmian kabupaten baru hasil pemekaran dari Kabupaten Asahan. Kabupaten baru ini terdiri 7 kecamatan, 98 desa, 7 kelurahan, dengan jumlah penduduk 374.715 jiwa, di mana 25.837 jiwa di antaranya warga miskin. Lihat pada gambar 4.1 dapat dilihat pada peta wilayah di atas geografis wilayah Batu Bara.

Di Kabupaten Batubara yang merupakan pemekaran dari Kabupaten Asahan, pernah hadir suatu kerajaan yang sampai sekarang bangunannya masih berdiri, namun sayang kurang mendapatkan perawatan dari pemerintah setempat baik itu dari Kabupaten Induk yakni Kabupaten Asahan, Kabupaten Batubara, dan pemerintah provinsi. Namun kini, sejak Batubara di mekarkan menjadi kabupaten, secara otomatis yang bertanggung jawab untuk merawat sejarah kebesaran kerajaan Melayu ini adalah Pemkab Batubara dan Pemkab Asahan sebagai kabupaten induk.

Berdasarkan Peraturan Bupati Batu Bara Nomor 3 Tahun 2007 ditetapkan bahwa hari jadi Kabupaten Batu Bara adalah pada tanggal 8 Desember 2006 sesuai dengan Persetujuan Bersama DPR RI dengan Presiden RI yang memutuskan undang-undang tentang pembentukan Kabupaten Batu Bara. Tertarik akan keberadaan bangunan sejarah yang teronggok tanpa mendapatkan perhatian serius dari Pemkab Asahan, Batubara, dan Provinsi Sumatera Utara, akhirnya penulis mencoba untuk menelusuri sejarah tentang awal berdirinya kerajaan ini. Sepintas dari depan terlihat warna hijau bangunan istana sudah kusam. Istana berlantai empat yang dibangun tahun 1912 itu sudah lapuk dimakan zaman dan tak menarik lagi dikunjungi. Mungkin karena kondisinya itu juga maka dalam brosur pariwisata Sumatera Utara, istana Lima Laras tidak tercantum lagi sebagai salah satu objek wisata. 
Gobuk atau Kesenian gobuk merupakan sebuah tradisi masyarakat pesisir yang digunakan untuk proses penyembuhan. Pada awalnya tari gobuk adalah sebuah upacara ritual pengobatan. Awal mula kesenian yang memuat tarian ini berawal pada sekitar tahun 1895 lalu ketika ada seorang warga Desa Nagur Kecamatan Tanjung Beringin yang merupakan anak dari seorang penguasa desa mengalami sakit (Aziz, 2011). Konon ceritanya, Siti Rofiah, seorang putri (anak perempuan) dari seorang kepala kampung terkena penyakit aneh. Berbagai pengobatan telah dilakukan. Obat-obatan tradisional dan ahli kesehatan kesultanan juga sudah mencoba menyembuhkan namun tetap tidak berhasil. gobuk merupakan sebuah benda dari tanah liat yang berbentuk seperti kendi. Pada zaman nenek moyang gobuk biasa dipakai sebagai tempat memasak air.

Orang tua Siti Rofiah kebingungan melihat anaknya tidak mengalami kesembuhan. Akhirnya setelah dilakukan perundingan dengan seluruh pihak keluarga dan saudara, diputuskanlah untuk memanggil datuk Pawang. Wan Syaifuddin (wawancara 2016) menyatakan bahwa pawang bagi masyarakat Melayu Pesisir Sumatera Utara adalah seorang yang mampu menggunakan kekuatan magis untuk memindahkan hujan, memindahkan makhluk halus atau jin dari kawasan hutan sewaktu penebasan hutan dan mampu mengusir jin jahat dari laut yang dijadikan sebagai kawasan penangkapan ikan. Kemudian dalam masyarakat melayu pawang mempunyai arti yang sama dengan dukun. Pawang diketahui mampu mengobati orang sakit melalui kekuatan magis atau batinnya. Selain itu pawang juga mampu membujuk dan menghalau makhluk halus baik jin atau roh jahat yang dianggap mempunyai kekuatan mengganggu kehidupan manusia.

Rofiandri (2018) dalam jurnalnya membahas bagaimana music berperan dalam iringan tari bagi etnis Melayu. Dalam tulisannya dibahas music mengiringi tari rentak bulian pada etnis Melayu.

\section{METODE}

Pada penelitian ini digunakan metode
Penelitian Desktiptif Kualitatif yang
memfokuskan pembahasan pada akulturasi
kebudayaan antara Minangkabau dan Melayu di
Batu Bara Provinsi Sumatera Utara khususnya daerah Sumatera Timur. Pengambilan data penelitian ini di daerah Kecamatan Tanjung Tiram Kabupaten Batu Bara, yang mengambil lokasi Penelitian di Sanggar/Lembaga Yusda Jalan Perintis Kemerdekaan, Desa Lalang Kecamatan Tanjung Tiram Kabupaten Batu Bara dan Penelitian dilakukan dari bulan dari Desember 2015 hingga Maret 2016, tetapi sebelum penelitian yang akan dilakukan, penulis melakukan observasi dan berdialog langsung dengan beberapa narasumber terkait dengan topik penelitian. Untuk mempermudah pengambilan data serta pengolahan data penelitian, maka yang menjadi populasi adalah seniman-seniman baik musik, tari yang memiliki sanggar di Kabupaten Batu Bara.

Sample dalam penelitian ini adalah sanggar Budaya atau Lembaga Kesenian Yusda. Pemilihan tiga sanggar ini sebagai sample penelitian dikarenakan, sanggar tersebut telah banyak mementaskan Tari Gobuk yang menjadi bahan penelitian, dan menjadi sanggar yang banyak mengikuti acara-acara pertunjukan, dari tingkat lokal, daerah maupun nasional.

Untuk mempermudah pengambilan data serta pengolahan data penelitian, maka yang menjadi populasi adalah seniman-seniman baik musik, tari yang memiliki sanggar di Kabupaten Batu Bara. Sample dalam penelitian ini adalah sanggar Budaya atau Lembaga Kesenian Yusda. Pemilihan tiga sanggar ini sebagai sample penelitian dikarenakan, sanggar tersebut telah banyak mementaskan Tari Gobuk yang menjadi bahan penelitian, dan menjadi sanggar yang banyak mengikuti acara-acara pertunjukan, dari tingkat lokal, daerah maupun nasional.Teknik pengumpulan data yang dilakukan melalui observasi langsung ke lokasi penelitian di Kabupaten Batu Bara Sumatera Timur Provinsi Sumatera Utara. Selanjutnya penelitian juga dilakukan dengan wawancara terhadap narasumber yang berhubungan dengan kebudayaan khusus tari dan musik. Dalam hal ini narasumber adalah pakar seni dan pakar budaya. Pengumpulan data juga dilakukan dari hasil dokumentasi berupa audio visual serta dokumentasi foto. Analisis data juga memuat hasil studi kepustakaan dari hasil penelitian 
terdahulu berupa data-data dan buku-buku mengenai etnis Melayu khusus di Batu Bara dan bagaimana penyeberannya sehingga terjadi akulturasi kebudayaan.

Setelah keseluruhan data dapat dikumpulkan dari lokasi penelitian, maka pada akhir penelitian penulis mendeskripsikan dan menganalisis keseluruhan data-data yang diperoleh dalam bentuk tulisan ilmiah untuk membuat sebuah kesimpulan yang dapat menjawab seluruh pertanyaan didalam penelitian.

\section{HASIL DAN PEMBAHASAN}

\section{Hasil Penelitian}

Adapun alat-alat musik yang digunakan dan fungsinya pada iringan tari Ritual Gobuk sendiri adalah sebagai berikut:

1. Gendang

Gendang merupakan alat musik perkusi atau alat pukul yang digunakan untuk mengiringi kegiatan ritual tradisi gobuk. Jumlah yang digunakan berjumlah tiga buah yang ukurannya sama dan boleh juga tidak sama. Untuk gendang para iringan ritual gobuk terdapat dua fungsinya yaitu, gondang anak dan gondang peningkah yang mengisi disela-sela gendang dua (hiasan nada) dan satu gendang lainnya sebagai pengiring atau pembawa tempo yang bermain secara konstan.

2. Biola

Biola digunakan sebagai alat musik yang mengiringi melodis pada iringan tari gobuk. Biola yang mengiringi iringan tari gobuk membawa suasana yang menjadikan suasana semakin mistis. Pada ritual mengusir roh atau mengobati penyakit, biola sering digunakan masuk ke dalam bagian alat musik yang digunakan. Jenis biola digunakan menggunakan biola pada umumnya. Tidak ada pemilihan khusus pada biola yang digunakan.

\section{Gong/Ogung/Tawak-tawak}

Gong yang digunakan pada musik iringan tari gobuk adalah gong yang berfungsi untuk sebagai pembawa tempo untuk iringan pada pertunjukan gobuk. Tapi pada ritual gobuk sendiri, terkadang ogung jarang digunakan karena tempo terkadang dibawa oleh gendang yang membawa ritme pada iringan ritual gobuk. Yang dipakai biasanya berukuran lebih kecil dari gong batak dan gong jawa. Dalam penyebutan lain gong biasanya juga disebut dengan istilah tawak-tawak.

\section{Talempong}

Alat talemong merupakan sebuah alat musik pukul tradisional khas suku Minangkabau. Bentuknya hampir sama dengan instrumen bonang dalam perangkat gamelan. Talempong dapat terbuat dari kuningan, namun ada pula yang terbuat dari kayu dan batu. Saat ini talempong dari jenis kuningan lebih banyak digunakan. Talempong memiliki lingkaran diameter 15 sampai $17,5 \mathrm{~cm}$, pada bagian bawahnya berlubang sedangkan pada bagian atasnya terdapat bundaran yang menonjol berdiameter lima sentimeter sebagai tempat untuk dipukul. Talempong memiliki nada yang berbeda-beda. Bunyinya dihasilkan dari sepasang kayu yang dipukulkan pada permukaannya. Talempong biasanya digunakan untuk mengiringi tarian pertunjukan atau penyambutan, seperti Tari Piring yang khas, Tari Pasambahan, dan Tari Gelombang. Pada iringan tari gobuk, talempong berfungsi sebagai ritem yang mengantarkan gendang untuk proses trance masuknya roh atau mambang yang akan masuk.

\section{Bansi}

Sebenarnya bansi hanya sebagai alat tambahan saja pada ritual iringan gobuk. Instrumen bansi hanya digunakan pada kegiatan tertentu saja. Seperti pertunjukan kesenian gobuk dan beberapa acara adat. Bansi atau Suling Minang dengan 7 lubang (seperti rekorder), berbentuk pendek, dan dapat memainkan lagu-lagu tradisional maupun modern karena memiliki nada standar (diatonik). Ukuran Bansi adalah sekitar 33,5 - $36 \mathrm{~cm}$ dengan garis tengah antara $2,5-3 \mathrm{~cm}$. Bansi juga terbuat dari talang (bambu tipis) atau sariak (sejenis bambu kecil yang tipis).

\section{Asal Mula Nenek Moyang Orang Batu Bara}

Berdasarkan wawancara dengan Bapak M. Yushar Harahap (tanggal 17 Maret 2016) Batu Bara sendiri berasal dari nama sebuah batu yang berwarna kemerah-merahan yang terletak di atas sebuah bukit yang daerahnya saat ini masuk ke dalam Kecamatan Lima Puluh. Terbentuknya masyarakat Batu Bara sendiri tidak terlepas dari cerita atau hikayat masuknya utusan-utusan dari Pagaruyung (Bukit Tinggi) yang dikirim kewilayah Pesisir Sumatera Timur.

Menurut Bapak Mustafa Akhyar (wawancara 20 Maret 2016), Batu Bara masyarakat Batu Bara sendiri sebenarnya bukan masuk ke dalam 
Melayu yang telah mendiami wilayah pesisir Timur Sumatra seperti, Siak, Deli, Serdang, Langkat, Asahan dan kerajaan-kerajaan Melayu disekitarnya. Melayu yang ada di Batu Bara berasal dari percampuran keturunan Pagaruyung dan penduduk dari pesisir yang membuat sebuah perkampungan di Wilayah Batu Bara.

Hal ini menyebabkan terlihat hampir miripnya dialek pada bahasa yang digunakan oleh orang Melayu yang ada di Batu Bara. Penggunaan kosakata dan dialek yang hampir sama dengan masyarakat Minangkabau, memperkuat adanya hubungan kekerabatan antara orang Batu Bara dan masyarakat etnis Minangkabau.

Keterkaitan tersebut juga terlihat dari samanya nama-nama beberapa kota yang ada di Batu Bara dan di Ranah Minang, di antaranya sama-sama memiliki kota Lima Puluh, Sei Bejangkar, Tanah Datar dan beberapa daerah lainnya. Wilayah Batu Bara telah dihuni oleh penduduk sejak tahun 1720 M, ketika itu di Batu Bara terdapat 5 (lima) suku penduduk yaitu Lima Laras, Tanah Datar, Pesisir, Lima Puluh dan Suku Boga. Kelima suku tersebut masing-masing dipimpin oleh seorang Datuk yang juga memimpin wilayah teritorial tertentu. Ketika itu Batu Bara menjadi bagian dari kerajaan Siak dan Johor. Untuk mewakili kerajaan Siak dan mengepalai Datuk-Datuk seluruh Batu Bara diangkat seorang Bendahara secara turun temurun. Setiap Datuk kepala suku mendapat pengangkatan dan capnya dari Sultan Siak.

Susunan pimpinan Batu Bara pada waktu itu ialah Bendahara dan di bawahnya terdapat sebuah Dewan yang anggota-anggotanya dipilih oleh Datuk-Datuk kepala suku bersama-sama.

Terjadinya Akulturasi Alat Musik Bansi (Minangkabau) Dalam Musik Iringan Tradisi Ritual Gobuk

Berdasarkan wawancara dengan Bapak Padil (wawancara tanggal 20 Maret 2016), sebenarnya Ritual Gobuk bukan sebuah asli kesenian Melayu. Ritual Gobuk sendiri dapat ditemukan di hampir seluruh wilayah pesisir di Sumatera Timur. Mulai dari di Langkat hingga Tanjung Balai. Kesenian Ritual Gobuk sendiri merupakan sebuah proses pengusurian terhadap roh halus yang masuk ke dalam tubuh manusia.

Dari rangkaian peristiwa persebaran nenek moyang masyarakat Batu Bara sendiri, dalam proses iringan tari pada ritual gobuk musik berperan sebagai salah satu proses rangkaian yang dijalankan. Musik menjadi media penghubung yang penting dalam berlangsungnya ritual. Dalam iringan musik yang dimainkan musik menjadi sarana untuk mencapai keadaan trance atau kerasukan.

Pada iringan tari ritual gobuk, gendang memegang peranan penting dalam mengiringi tari. Ini disebabkan gerak dari para penari terasa hidup dan dinamis tergantung kepada kemampuan menggendang. Sedangkan alat musik biola merupakan pembawa jalan melodis yang membawa suasana menjadi lebih indah.

Adapun alat musik bansi sebenarnya digunakan sebagai tambahan untuk menambah varian dalam musik yang mengiringi tari pada ritual gobuk. Alat musik bansi menjadi tambahan melodi untuk memperbanyak melodi-melodi yang dibawakan oleh biola agar lebih membuat suasana menjadi mistis, religius dan terasa akan kehadiran dari mambang.

Terjadinya akulturasi menurut Bapak Padil (wawancara 20 Maret 2016) alat musik bansi ikut dimasukkan ke dalam iringan musik pengiring tari gobuk bersama dengan alat musik lainnya, seperti talempong, ogung, dan alat musik melayu. Alat musik bansi berakulturasi bersama kebudayaan minangkabau yang telah ada dan masuk ke dalam masyarakat Melayu di Batu Bara.

\section{Pembahasan}

\section{Bentuk Penyajian Pertunjukan Musik Iringan dan Tari Gobuk Melayu}

Pertunjukan tari tradisi gobuk bersifat teatrikal. Pada dasarnya bentuk pertunjukan tari gobuk tidak mengalami perubahan yang signifikan dalam bentuk penyajian dari awal terbentuknya pertunjukan ini. Namun seiring pergantian zaman, tari gobuk mengalami pengembangan fungsi, dari hanya sekedar ritual pengobatan menjadi seni pertunjukan yang menjadi hiburan masyarakat. Sebagaimana dijelaskan dibagian awal tulisan ini bahwa unsur pembentuk pertunjukan tari gobuk terdiri dari musik, tari, senandung, mantra, pantun, penyerahan sesajen dan menghanyut lancang kuning.

1. Tahap Persiapan

2. Tahap Kerasukan 
3. Tahap Kesadaran

4. Penutup

\section{Fungsi Kesenian Ritual Gobuk Bagi Masyarakat Melayu Pesisir Di Kecamatan Tanjung Tiram Kabupaten Batu Bara}

Fungsi dari kesenian Ritual Gobuk pada masyarakat Melayu di Batu Bara menurut Bapak Padil (wawancara 20 Maret 2016), dapat dikelompokkan pada beberapa fungsi. Adapun fungsi-fungsi dalam iringan tari gobuk sebagai berikut :

1. Sebagai Ritual/Adat

2. Sebagai Penyembuhan

3. Seni Pertunjukan

\section{KESIMPULAN}

Berdasarkan dari uraian di atas dapat diambil kesimpulan dari hasil penelitian ini. Kesimpulan tersebut untuk menjawab pokok permasalahan yaitu mengenai Akulturasi Alat Musik Bansi (Minangkabau) pada iringan tari kesenian Gobuk di Kecamatan Tanjung Tiram. Peneliti dapat menarik kesimpulan antara lain :

1. Alat musik yang digunakan pada tradisi gobuk antara lain, gendang, gong atau tawak-tawak, bansi, dan biola.

2. Nenek Moyang masyarakat Batu Bara berasal dari pagaruyung (Bukittinggi) Sumatera Barat.

3. Proses terjadinya akulturasi alat musik bansi terjadi akibat ikutnya terjadi persebaran nenek moyang masyarakat Batu Bara sendiri yang dominan berasal dari pagaruyung (Bukittinggi).

4. Bentuk dan penyajian tradisi gobuk melalui beberapa tahapan yaitu tahap persiapan ritual, tahap kerasukan, tahap kesadaran, dan tahapan penutupan.

5. Fungsi dari tradisi gobuk sendiri dapat dikategorikan pada beberapa hal, yaitu; sebagai ritual, sebagai penyembuhan dan sebagai pertunjukan.

\section{DAFTAR PUSTAKA}

Arikunto, Suharsimi. 2006. Prosedur Penelitian. Jakarta : PT. Rineka Cipta.

Batubara, Santy Mayda. "Kearifan Lokal dalam Budaya Daerah Kalimantan Barat (Etnis Melayu dan Dayak)." Jurnal Penelitian IPTEKS 2.1 (2017).

Budaya, Arga. "Alat Musik Tiup: Bansi Dalam Ritual Penyadapan Enau Di Nagari Saruaso
Minangkabau." Ekspresi Seni: Jurnal Ilmu Pengetahuan dan Karya Seni 14.1 (2012).

Raharja, Budi. "Musik Iringan Drama Tari Pengembaraan Panji Inukertapati Bermisi Perdamaian dan Toleransi." Resital: Jurnal Seni Pertunjukan (Journal of Performing Arts) 20.1 (2019): 13-23.

Endraswara, Suwardi, 2006. Metode, Teori, Teknik Penelitian Kebudayaan. Pustaka Widyatama, Sleman.

Fahlafi, Ridha Faluthia, Taat Kurnita, and Aida Fitri. "Penyajian musik iringan Tari Likok Pulo di Pulau Aceh Kabupaten Aceh Besar." Jurnal Ilmiah Mahasiswa Pendidikan Seni, Drama, Tari \& Musik 1.4 (2016).

Pelly, U. (1994). Urbanisasi dan Adaptasi : Peran Misi Budaya Minagkabau dan Mandailing, Jakarta: LP3ES

Hajizar, Hajizar. "Tradisi Musik Rabab Di Daerah Pesisir Minangkabau (Rabab Piaman Dan Rabab Pasisia)." LAGA-LAGA: Jurnal Seni Pertunjukan 5.2 (2019): 184-200.

Hidayat Robby M.Sn. 2005. Wawasan Seni Tari. Fakultas sastra Universitas Negeri Malang.

Havilland, A. William. 2009. Function And Form of Presentation of Musical Traditions.

Koentjaraningrat, 2006. Metode Penelitian. Bandung. Alfabeta.

Langer, K. Suzanne. 2006. Studies in Music And Culture.

Licoln, Guba. 2006. Teknic in Perticipant Observation for Observes Reaserc. Wikipedia, The Encylopedia.

Purnomo, S. "Bentuk Penyajian Tari Sarah Hadralmaut Pada Masyarakat Melayu Di Desa Nagur Kabupaten Serdang Bedagai." Gesture: Jurnal Seni Tari 4.1 (2015).

Purnomo, Try Wahyu, and Sri Mustika Aulia. "Kajian Organologi Alat Musik Saluang Pauh Buatan Zulmasdi di Kota Padang." Gondang: Jurnal Seni dan Budaya 4.1: 28-37.

Rahayu, Tuti. 2005. Upacara Adat Siar Mambang di Kabupaten Asahan. Medan. Tesis : Unimed.

Robert Redfield, Ralph Linton dan Melville J. Herskovits. Memorandum for the Study of 
Acculturation. American Anthropologist, Vol. 38 No. 1 (Januari-Maret 1936), h. 136.

Siegmeister, Elie. 2004. Melody as the metion of a single voice or instrument. New York :Wesley

Soekarno.2002. Paduan Olah Vokal. Jakarta: Media Pressindo.

Spradlley.2002. Analysist of Kind Involve a Way of Thinking. New York :Wesley

Susan Stainback. 2009. Teknik in how about make a good musik. Wikipedia, The Encylopedia.

Simamora Elisabeth.2003. Proses Upacara Perkawinan Adat Sumando Pada Masyarakat Pesisir di Kota Sibolga.Medan.FBS Unimed.

Suardi, Rofiandri. "Musik Tari Rentak Buliandi Sanggar Kamboja SMPN 1 Rengat Kabupaten Indragiri Hulu Provinsi Riau (Analisis Unsur Melodi)." Virtuoso (Jurnal Pengkajian dan Penciptaan Musik) 1.1 (2018): 1-7.

Sugiyono.2010. Metode Penelitian Kuantitatif, Kualitatif dan $R \& D$, Bandung : Alfabeta

Syafrayuda, Diah Rosari. "Eksistensi Tari Payung sebagai Tari Melayu Minangkau di Sumatera Barat." Ekspresi Seni: Jurnal Ilmu Pengetahuan dan Karya Seni 17.2 (2015): 180-203.

Nduru, Mudilia.2005. Perana Musik Dalam Tari Maena Pada Upacara Adat Perkawinan Masyarakat Nias di Desa Tundrumbaho Kecamatan Lolomatua. Medan.FBS Unimed.

Takari, Muhammad.2009. Kebudayaan Melayu di Sumatera Timur.Medan:USU press.

The Free Dictionary.2010. Dictionary, Encyclopedia and Thesaurus. USA: http://www.thefreedectionary.com

Wati, Maysar Ika.2006. Musik Tradisional Simalungun Pada Pesta Perkawinan di Desa Sei Buaya Kab Deli Serdang. Medan. FBS Unimed. 